\title{
Competence Relationship with Organizational Excellence JKKK in Kuala Nerus, Terengganu
}

\author{
Aduwina Pakeh \\ Teuku Umar University \\ Faculty of Social and Political Sciences \\ aduwina@utu.ac.id
}

\begin{abstract}
Organizational excellence is defined as the overall organization of corporate management and the entire organization is operated and create a world-class organization. The concept of organizational excellence providing the means to carry out its mission and achieve its objectives. A Village Development and Security Committees or Jawatankuasa Kemajuan dan Keselamatan Kampung (JKKK) is an institution of leadership at village level which was established by government as an administration organization and coordination of community development especially in rural sector. JKKK is an organization which has the function as agent of change or an operator agent between government and community of village. This study was identified the relationship between competency and organization excellence. Design of survey was conducted by using quantitative method based on stratified and random sampling. Research instrument for this study was by using questionnaire form. Meanwhile, this study has selected 109 committees in 15 villages (JKKK) were selected from four State Legislative Assembly (DUN) in Kuala Nerus, Terengganu. Conclusion of this study is competence has significant positive relationship with the organization excellence $(r=0.786, p<0.01)$. Base on the conclusion of this study can be formulated that JKKK as a lower leader should have high level of competency and skill in management to give the best services for community. They have to actively participate in various development activities. It requires of building a skills training program systematically to train every member of JKKK in fulfilling their responsibilities as a leader at grass root level.
\end{abstract}

Keywords: JKKK, Relationship, Competence, Organizational Excellence,

\section{INTRODUCTION}

\section{Background of the study}

Village Development and Security Committee or JKKK is a summary of leadership at the village level institutions created by the government in its efforts to develop rural communities. JKKK is the body which acts as a change agent and an important link between the government and villagers. The establishment of the JKKK to create space and give a chance to the people to be involved in the development process at the village level(Mohd Yusof, 2003).

Table 1: Number of JKKK Malaysia by State 2010

\begin{tabular}{|l|l|l|}
\hline No. & State & Number JKKK \\
\hline 1. & Johor & 666 \\
\hline 2. & Kedah & 1,899 \\
\hline 3. & Kelantan & 597 \\
\hline 4. & Melaka & 232 \\
\hline 5. & Negeri Sembilan & 381 \\
\hline 6. & Pahang & 542 \\
\hline 7. & Perak & 818 \\
\hline 8. & Perlis & 371 \\
\hline 9. & Pulau Pinang & 142 \\
\hline 10. & Sabah & 2,699 \\
\hline 11. & Sarawak & 5,448 \\
\hline
\end{tabular}


Table 1, cont.

\begin{tabular}{|l|l|l|}
\hline 12. & Selangor & 381 \\
\hline 13. & Terengganu & 985 \\
\hline 14 & Wilayah Persekutuan Labuan & 27 \\
\hline & Total & $\mathbf{1 5 , 1 8 8}$ \\
\hline
\end{tabular}

Source: Malaysia, 2010

Based on Table 1 above, the JKKK in Malaysia has reached a total of 15.188 units. State ranked first with a total of 5,448 pieces JKKK while the Federal Territory of Labuan to be the smallest of the 27 JKKK. The Terengganu state itself of 985 pieces JKKK (Malaysia, 2010). JKKK organization in this country begin simultaneously with the launch of the Second Malaya Plan (1961-1965) on September 4, 1961. During the first established, the committee is known as the Village Development Committee (JKKK). Then in 1975, its name was changed to Village Development and Security Committee (JKKK) as an additional task to maintaining the safety and security of the village from the threat of outsiders. JKKK is the mechanism identified to help achieve that goal at the grassroots level to generate the involvement of villagers in the draft local development and expressed his wishes, needs, and problems that can not be resolved itself to a higher level above that can be highlighted and acted (Mohd Yusof, 2003).

JKKK oversee the development of the village as well as acting as a mechanism of interaction among the various social institutions in the village. JKKK, consisting of village leaders elected from representatives of all village organizations. JKKK each consisting of a chairman, deputy chairman, secretary, treasurer, and 11 committee members (AJK).

The JKKK is to identify, design, implement, and oversee development projects at the village level that cover aspects such as socio-economic, educational, religious, health and safety of the village. Following the administration of the district office, the latter acting as a liaison between the village and the government, as well as linking the village with the government agencies and responsible for development projects.The committee is also responsible for directing and coordinating the resources of the village in order to ensure the development of society, also to maintain a stable and secure environment that is free from social threats such as drug abuse among youth (Munirah, 1997).

Its roles are very important in a village, especially for the community. JKKK as government organizations that are closest and in direct contact with the public. JKKK is spearheading the administration of the State, the latter being required to demonstrate the ability of governance, particularly in providing services to villagers. JKKK members are required to master the professional and good at his job and has high moral commitment as directed by the State Government. JKKK is a subject that should encourage the active participation of villagers in activities that can achieve the development goals of the village.

In addition, based on discussions with several leaders researchers JKKK in Kuala Nerus, Terengganu, researchers have found they have expressed various difficulties encountered in the administration of the village. First, the chairman of JKKK apprehend matters related to the level of understanding and knowledge ali-members towards the goals, mission and vision of the JKKK. Second, they also feel the lack of the ability of the members in carrying out its role or activities given its responsibility for the lack of efficiency. Third, the existence of some members who are not proactively involved in various programs organized by JKKK. Furthermore, the presence of some leaders JKKK which is not settled in the village which he heads, they sat dikampung other.

Based on local issues raised, the researchers feel is an ongoing need for a scientific study to answer the problems that occur in the organization JKKK in Kuala Nerus. This study was decided to investigate the relationship between competency and organizational excellence JKKK in Kuala Nerus, Terengganu. This study only focus on two factors, namely the competence and organizational excellence. 


\section{Concept Definition}

\section{Competence}

Competence concept first brought by Selznick (1957) dan McClelland (1973) using its own competence to reflect corporate advantage through various value activities. Competence is the most important factor to accomplish specific tasks (Yang et al., 2006; Nasir, 2012; Abdullah \& Sentosa, 2012). Chouhan dan Srivastava (2013)defines competence as skills, personal characteristics or patterns of behavior shown by many who contributed to the excellent performance in the job. Competence is a set of knowledge, skills and attitudes needed to perform the job effectively and efficiently, which results in outstanding performances in the workplace.

\section{The Organizational Excellence}

The concept of organizational excellence as a topic of academic research and debate by Peters and Waterman (1982) in their book "In search of excellence"(Hermel \& Ramis-Pujol, 2003;job \& Bhattacharyya, 2010; Antony \& Bhattacharyya, 2010; Nambiar \& Kennedy, 2012; Job \& Kamalanabhan, 2014). Over the past 20 years, both the definition and the assessment of the sustainability of excellence has undergone repeated changes(Hermel \& Ramis-Pujol, 2003). By Antony and Bhattacharyya (2010), assessment of excellence is an organizational assessment process of continuous improvement model in an effort to highlight what has been achieved and what needs improvement.

Organizational excellence, according to Antony and Bhattacharyya (2010) can be viewed and calculated based on the relationship between various variables of performance. Excellence is considered as the highest level of performance. Currently, many organizations are looking for organizational excellence, but not all are lucky because most of them can not achieve this goal because of lack of understanding of organizational excellence (Dahlgaard-Park, 2009).

\section{METHODOLOGY}

As the researchers describe the causal, quantitative approach is feasible. According to Sugiyono (2010), the approach of quantitative research as a method of study that is based on the philosophy of positivism, is used to examine the population or a particular sample, the sampling technique is usually done at random, collecting data using questionnaires, data analysis, quantitative / statistical aim to test the hypothesis that has been set

Through the quantitative approach, the results were analyzed and discussed in the form of tables, diagrams and statistical estimates. The quantitative approach has the advantage of avoiding the bias that can occur between the researcher and the study sample (Andrew \& Halcomb, 2009).

This study used a survey design. Survey cross (cross-sectional survey) is to get the information data with a sample of a population in a timely manner. Data were analyzed using descriptive and hypothesis testing methods. Methods of correlation and causality used to answer the hypothesis.

\section{Study Location}

Terengganu State has seven districts, namely Kemaman, Dungun, Hulu Terengganu, Marang, Kuala Terengganu, Setiu and Besut. Almost all districts in Terengganu is located on the coast except Setiu located in remote areas. Each area is broken down into several sub-districts. The study was conducted in Mukim Kuala Nerus which is located in Kuala Terengganu.

Kuala Nerus is one of the existing districts in Kuala Terengganu, which has the largest population than any other sub-districts (see Table 2). Also inhabited by citizens of various races including the Malays, Chinese, Indians and other ethnic groups, there are also foreign citizens who inhabit this area. 
Table 2: Estimated Population by Reuters in Kuala Terengganu, 2010

\begin{tabular}{|lc|}
\hline Mukim & $\begin{array}{c}\text { Estimated } \\
\text { Population (People) }\end{array}$ \\
\hline Atas Tol & 2,900 \\
Bandar & 12,279 \\
Kuala Terengganu & \\
Batu Buruk & 13,852 \\
Batu Rakit & 37,163 \\
Belara & 17,648 \\
Bukit Besar & 22,929 \\
Cabang Tiga & 14,448 \\
Cenering & 13,811 \\
Gelugur Kedai & 6,605 \\
Gelugur Raja & 2,083 \\
Kepung & 7,131 \\
Kuala Ibai & 13,316 \\
Kuala Nerus & $\mathbf{8 3 , 7 9 3}$ \\
Kubang Parit & 7,379 \\
Losong & 9,401 \\
Manir & 28,428 \\
Paluh & 8,787 \\
Pengadang Buluh & 14,263 \\
Pulau Redang & 2,013 \\
Pulau-Pulau & 3,945 \\
Rengas & 3,009 \\
Serada & 7,177 \\
Tok Jamal & 5,193 \\
\hline Jumlah & $\mathbf{3 3 7 , 5 5 3}$ \\
\hline
\end{tabular}

Source: Department of Statistics Malaysia (2010)

Kuala Nerus is an area that is undergoing rapid development and progress. There are several institutions of higher learning here as two public universities, namely Universiti Malaysia Terengganu (UMT) and Universiti Sultan Zainal Abidin (UNISZA); there is also a teacher training institute and some boarding schools like Maktab Rendah Sains MARA (the college) and technical schools.

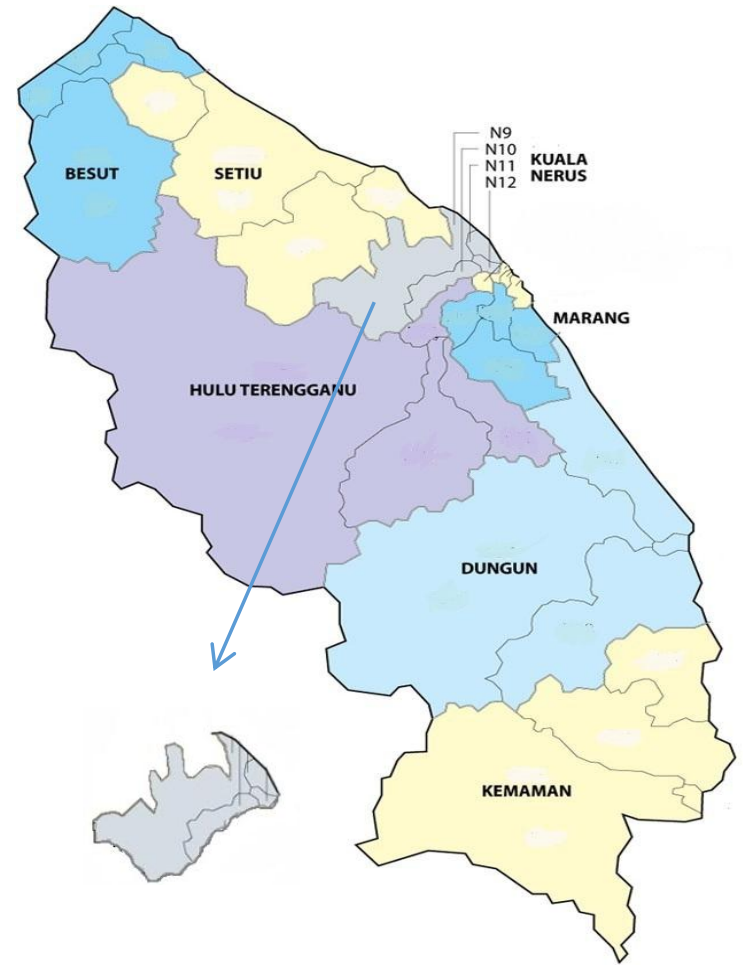

Map 1. Kuala Nerus, Kuala Terengganu 


\section{Population and Sample}

The population is defined as a set of characteristic absorption or measure specific to the individual or group objectives. Population determines the problem to be studied, and also determine the extent to which data or information should be collected and analyzed (Mohd Majid Konting, 2004). According to Ahmad Mahdzan (2005) population is defined as a group of entities, elements, objects or object (whether animate or inanimate) respondents (or case studies) for a researcher.
The population in this study were all members of the JKKK is in Kuala Nerus parliamentary constituency. Based on data District and Land Office of Kuala Terengganu (PDTKT) in 2014 recorded a total JKKK in Kuala Nerus parliamentary constituency of 105 pieces. Each JKKK consists of 15 members (a Chairman, Deputy Chairman, Secretary, Treasurer and 11 persons AJK). Table 3 shows the number of JKKK, JKKK number of members, and the percentage of gender in the state assembly.

Table 3: Number of JKKK members in the constituency of Kuala Nerus

\begin{tabular}{|l|lcccc|}
\hline \multirow{3}{*}{ PARLIMEN } & DUN & $\begin{array}{c}\text { Number } \\
\text { of Village } \\
\text { / JKKK }\end{array}$ & $\begin{array}{c}\text { Number } \\
\text { of JKKK }\end{array}$ & Male & Female \\
\hline \multirow{5}{*}{ Kuala Nerus } & Tepoh & 34 & 510 & 382 & 128 \\
& Teluk Pasu & 31 & 470 & 372 & 98 \\
& Seberang Takir & 14 & 210 & 167 & 43 \\
& Bukit Tunggal & 26 & 388 & 293 & 95 \\
\hline Total & 4 & 105 & 1,577 & 1,213 & 364 \\
\hline
\end{tabular}

Source: District and Land Office of Kuala Terengganu, 2014

In this study, researchers used a stratified random sampling techniques and random. Mechanical stratified random sampling involves a process in which the population is broken down into groups that have the same properties or homogeneous, so the sample is chosen randomly from each group (Sidek Mohd Noah, 2002) techniques have been because JKKK in Kuala Nerus classified into several DUN.

In this study, the sample size was determined based on the formula for determining the sample size Slovin (1960). Umar (2003) states that in order to determine the required minimum sample if the population is known, can use a formula Slovin. Based on the number of population JKKK members Kuala Nerus parliamentary constituency of 1,577 people, the number of samples is determined as follows;

$$
\mathrm{n}=\frac{N}{1+N e^{2}}
$$

\begin{tabular}{|c|c|c|}
\hline Where; & $\mathrm{n}$ & $=$ \\
\hline & $\mathrm{N}$ & $=$ \\
\hline offense 10 & $e^{2}$ & $=$ \\
\hline
\end{tabular}

Based on this formula, the sample size, $\mathrm{n}$ of this study is;

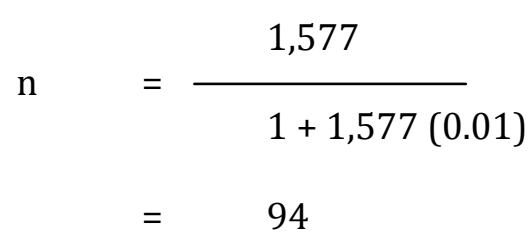

Or rounded up to 100 people.

According to Roscoe (1975 in Mohd Yusri, 2012), the appropriate sample size in most studies is in the range of 30 to 500. This study establishes minimum sample size of 100 people JKKK members. 
Table 4: Sampling Procedures ( $M=$ Male, $F=$ Female $)$

\begin{tabular}{|c|c|c|c|c|c|c|c|c|}
\hline $\begin{array}{c}\text { The number of } \\
\text { samples }\end{array}$ & \multicolumn{8}{|c|}{100 members } \\
\hline DUN & \multicolumn{2}{|c|}{$\begin{array}{c}\text { Tepoh } \\
\text { (32 Ahli) }\end{array}$} & \multicolumn{2}{|c|}{$\begin{array}{c}\text { Seberang } \\
\text { Takir } \\
\text { (13 Ahli) }\end{array}$} & \multicolumn{2}{|c|}{$\begin{array}{c}\text { Teluk Pasu } \\
\text { (30 Ahli) }\end{array}$} & $\begin{array}{r}\text { B } \\
\mathrm{Tu} \\
25\end{array}$ & \\
\hline \multirow{2}{*}{ Gender } & $\mathrm{M}$ & $\mathrm{F}$ & $\mathrm{M}$ & $\mathrm{F}$ & $\mathrm{M}$ & $F$ & $\mathrm{M}$ & $\mathrm{F}$ \\
\hline & 24 & 8 & 10 & 3 & 24 & 6 & 19 & 6 \\
\hline
\end{tabular}

\section{RESULTS AND DISCUSSION}

\section{Respondent Demographics}

The results showed that adults (41-55 years) dominated administration in various JKKK committee, unless the chairmanship. For the chairmanship, compared with youth and adults, research shows the majority of the elderly (56 years and above), is due to the "seniority" is still a consideration in the determination of the JKKK especially for the chairmanship. While members of the majority of youth aged JKKK office committee, because the committee members as the lowest positions in the administration with its bustling JKKK. In each JKKK, there are 11 committee members. Therefore, the selection committee into office for members of the youth to get involved in administration JKKK. The youths are still in the learning stage of administration, so it is fair for the first phase of the office entrusted to them AJK. However, there are also youths who holds the committee chairman, deputy and secretary, but still a very small percentage.

In this study educational categories divided into three levels, namely low levels (UPSR down), moderate (SPM and STPM or equivalent) and higher level (diploma or its equivalent, bachelor's degree and above) from the aspect of education, members of the JKKK majority have a moderate level education Sijil Pelajaran Malaysia (SPM) and STPM or equivalent (73 per cent). Followed by post-UPSR down and Certificate / Diploma respectively equivalent of 13 per cent. While only one JKKK members who have a bachelor's degree. For tarmac roads, which have a certificate of SPM and STPM is included in the medium level, if there are some members who hold diploma certificates and to top it included bonuses for JKKK.

The study found that most of the youths have medium and high levels of education, ie a total of 92 per cent. Member JKKK adults also had a simple majority of the level of education, only a small number of adults who have a higher education level. While the majority of the elderly JKKK members have a level of education that is simple and low, reaching 85 percent. However, a small number (15 percent) of the JKKK elderly who have high educational level.

The findings show that the majority of the JKKK in this study are those living in the constituency Tepoh which consist of 32 percent, followed by expert living in Teluk Pasu constituency and Bukit Tunggal, each of 30 and 29 percent. DUN while Seberang Takir an area of at least the number of members of the JKKK of 11 percent, due in constituency number JKKK Seberang Takir fewer than three other state seats under the constituency of Kuala Nerus. Based on the distribution of the JKKK members in office, the majority of members in office AJK which were 64 per cent, followed by the deputy chairman is 14 percent. While the chairman and secretary, respectively 10 per cent and 7 per cent. JKKK members in office treasurer in this study a total of only 5 percent.

On average, members of the Kuala Nerus JKKK has served for 9 years. The majority of 
members have been with the JKKK between 5 to 10 years which is about 70 percent. While JKKK members who have served the JKKK in a very long period of time (16 years and above) shows a total of 30 per cent. For the JKKK members serve a maximum of 27 years and the minimum is one year.

The results showed that more than half the members of the Chairman of JKKK has served in a very long period of time (55 percent), followed by the treasurer who is also the majority served in Sagat long period of time (60 percent). JKKK members who served as deputy chairman of the majority is not so long served the JKKK (medium), namely a total of 47 per cent. AJK majority positions are filled by youths also showed his tenure in the JKKK with the moderate (41 percent), followed by committee members who served for a long time (6-10 years) were 38 per cent. Only a small portion or a total of 22 percent of the committee members who have served in a very long period (Table 4.12).
The results showed that most of the youths had been served with JKKK within the medium (64 percent). Following a long period of service (6-10 years). For the adults showed that nearly half the members have served for a long time ( 40 percent). While for the older members of the JKKK JKKK has served in a very long period of time and old (11 years of age and 5-10 years), a total of 73 per cent. But there are also members of the older generation of his tenure with the JKKK still short or medium.

\section{Perception JKKK members to Level Organizational Excellence}

A total of 84 respondents felt the level of excellence is high JKKK organization representing 77.8 percent of total respondents. The perception of organizational excellence demonstrated high JKKK members are not satisfied with the achievements so far JKKK.

Table 5: Distribution of Respondents by Level Organizational Excellence

\begin{tabular}{|lcccc|}
\hline Variable / level & $\begin{array}{c}\text { Frequenc } \\
\mathrm{y}\end{array}$ & $\begin{array}{c}\text { Perce } \\
\mathrm{nt}\end{array}$ & $\begin{array}{c}\text { Mea } \\
\mathrm{n}\end{array}$ & $\begin{array}{c}\text { Standard } \\
\text { deviation }\end{array}$ \\
\hline Organizational & & & 4.06 & 0.49 \\
Excellence & & & & \\
Low (1.00-2.33) & 0 & 0 & & \\
Medium $(2.34-3.67)$ & 24 & 22.2 & & \\
High (3.68-5.00) & 84 & 77.8 & & \\
Total & 108 & 100.0 & & \\
\hline
\end{tabular}

Table 5 below shows the respondents to the level of excellence in Kuala Nerus JKKK organization. The findings indicate that item get the highest mean JKKK managed to establish good cooperation relationship with various agencies / bodies for the sake of progress outside the village with a mean of 4.454 as the most outstanding; followed by JKKK successfully listed programs that are most needed by the villagers with 4,315 min. Next JKKK formed the village developed $(4,306)$. The findings also showed two simple items of excellence according to the respondents in aspects such as JKKK successful upgrade salaries or benefits for members of the organization from time to time $(3,426)$; and JKKK have a good website, update and provide a positive influence on people $(3,631)$.

Overall, 22 items have been prepared according to organizational excellence min levels as shown in Table 6.10. Mean level is among the lowest to the highest of 3,426 $4: 45$. The min-min when min is classified into three categories according to Table Analysis Mean Score (Table 3.9.1); the JKKK in Kuala Nerus has 20 items of excellence at the high level (90 per cent). While the two items again in the medium level of 
excellence (10 percent). The mean total is 4,060 (high level) and a standard deviation of 0,802 . There are 13 items in which the mean value obtained exceeds the mean value of the average (mean 4.060) while nine more items have a mean value below the mean average.

\section{Relationship between Competence with Organizational Excellence}

Correlation analysis competencies with organizational excellence conducted to answer the research questions. The correlation of 3 types of competencies (individual competence, competence management and leadership and competence spiritual) with organizational excellence shown in Table 7.5. Among the findings were the dimensions of individual competence has a strong significant relationship with organizational excellence ( $\mathrm{r}=0.708, \mathrm{p}<0.01)$, has a simple relationship with competency management and leadership ( $\mathrm{r}=0.458, \mathrm{p}<0.01$ ) and had a poor relationship with spiritual competency ( $r=0.245, p<0.05$ ). This means that the dimensions of individual competence has a significant relationship with organizational excellence, also has a significant relationship with management and leadership competency dimension and spiritual competence.

The dimensions of management and leadership competencies were found to have a moderate positive relationship with organizational excellence and significant $(\mathrm{r}=$ $0.444, \mathrm{p}<0.01$ ), and has a simple relationship with an individual's competency ( $r=0458, p<0.01)$. Whereas management and leadership competencies found to have no significant relationship with the spiritual dimension of competency $(r=0.163, p>$ 0.05). This means competence JKKK members of management and leadership competence dimension was found to have a significant relationship with organizational excellence, but had no significant relationship with the spiritual dimension of competence. For the spiritual dimension of competence is also found to have a moderate positive relationship with organizational excellence $(r=0.543, p<0.01)$. 
Table 6: Relationship Between Competency With Organizational Excellence By Dimensions variable

\begin{tabular}{|c|c|c|c|c|c|}
\hline Correlation & & & & & \\
\hline & & $\begin{array}{l}\text { Individual } \\
\text { Competencie } \\
\mathrm{S}\end{array}$ & $\begin{array}{l}\text { Management } \\
\text { and leadership } \\
\text { competencies }\end{array}$ & $\begin{array}{l}\text { Spiritual } \\
\text { competencie } \\
\text { s }\end{array}$ & $\begin{array}{l}\text { Organizational } \\
\text { of Exellence }\end{array}$ \\
\hline Individual & Korelasi Pearson & 1 & & & \\
\hline Competencies & Sig. (2-tailed) & & & & \\
\hline Management & Korelasi Pearson & $.458^{* *}$ & 1 & & \\
\hline $\begin{array}{l}\text { and leadership } \\
\text { competencies }\end{array}$ & Sig. (2-tailed) & .000 & & & \\
\hline Spiritual & Korelasi Pearson & $.245^{*}$ & .163 & 1 & \\
\hline Competencies & Sig. (2-tailed) & .010 & .092 & & \\
\hline Organizational & Korelasi Pearson & $.708^{* *}$ & $.444^{* *}$ & $.543^{* *}$ & 1 \\
\hline of Excellence & Sig. (2-tailed) & .000 & .000 & .000 & \\
\hline
\end{tabular}

There $r$ Pearson correlation analysis was performed on variables competencies with organizational excellence after landing was to compute the dimensions of the variables.
Results of correlation analysis showed significant competency has a strong relationship with the organizational excellence $(r=0.786, p<0.01)$.

Table 7: Relationship Between Competency With Organizational Excellence

\begin{tabular}{|lll|}
\hline & $\begin{array}{l}\text { Organizational of } \\
\text { Excellence }\end{array}$ \\
\hline Competence & Correlation & $.786^{* *}$ \\
& person & \\
& Sig. (2-tailed) & .000 \\
$\mathrm{~N}$ & 108 \\
\hline
\end{tabular}

**Correlation is significant at the level $\mathrm{p}<0.01$ (one-tailed)

*Correlation is significant at the level $\mathrm{p}<0.05$ (two-tailed)

According to Table 7 of competence available variables have a significant positive relationship with organizational excellence $(\mathrm{r}=0.786, \mathrm{p}<0.01)$. This means competency has a strong significant relationship with organizational excellence. $\mathrm{R}$ value of .786 indicates a strong positive correlation. Consequently, Hypothesis H2c stating there is a significant relationship between competence and excellence organization failed rejected.

Summary results of the analysis show the test results of Pearson correlation between variables role and competence with excellence JKKK organization. The findings indicate that a simple relationship exists between the role and competence $(\mathrm{r}=.523)$, as well as the relationship between the role of organizational excellence $(r=.484)$ is a powerful medium. While the correlation between competence and excellence organization $(\mathrm{r}=.786)$ is strong. All correlations are significant at $\mathrm{p}<0.01$.

\section{CONCLUSION}

Overall, this study was able to prove that competency is an important factor to achieve excellence in an organization, in this case the JKKK organization. Therefore, it is appropriate stakeholders at state and national levels taking into account the 
increasing level of competence JKKK members to the organization can achieve excellence. This increased level of competency can be done by expanding the courses or workshops.

The correlation of three-dimensional competency (competency Individual competency management and leadership and competence spiritual) with organizational excellence is found, the dimensions of individual competence has a strong significant relationship with organizational excellence, also has a significant moderate relationship with dimensions of competency management and leadership and have a significant relationship weak with competence spiritual dimension.

The dimensions of management and leadership competencies were found to have moderate significant relationships with organizational excellence and individual competence dimensions. While the spiritual competence found to have no significant relationship. For the spiritual dimension of competence were found to have a significant correlation with simple organizational excellence.

The conclusions of the study results showed cumulative competence factors have a strong relationship with the organizational excellence among the JKKK members. Therefore, there is a need for management and top leadership to give special attention to the competence of the people of the JKKK to ensure excellent organization as expected.

\section{THANK YOU}

The author would like to thank the government of Aceh in particular to the Aceh governor dr. H. Zaini Abdullah who has provided financial support so that the study can be completed properly and on time.

\section{REFERENCES}

Antony, J. P., \& Bhattacharyya, S. (2010). "Measuring organizational performance and organizational excellence of SMEs Part 1: a conceptual framework", Measuring Business Excellence, Vol. 14 No. 2, pp. 3-11. McClelland, D. C. (1973),"Testing for Competence Rather Than for "Intelligence", The American Psychologist, Vol. 28 Eds. Januari, pp. 114.

Sugiyono. (2010). Metode Penelitian Kuantitatif Kualitatif dan R\&D. Bandung: Alfabeta.

Chouhan, V. S., \& Srivastava, S. (2013). "Competency Mapping For HR Professionals In IT Industry", The International Journal of Management, Vol. 2 No. 3, pp. 1-6.

Dahlgaard-Park, S. M. (2009). "Decoding the code of excellence - for achieving sustainable excellence",International Journal of Quality and Service Sciences, Vol. 1 No. 1, pp. 5-28.

Hermel, P., \& Ramis-Pujol, J. (2003). "An Evolution of Excellence: Some Main Trends",The TQM Magazine, Vol. 15 No. 4, pp. 230-243.

Job, P. A., \& Bhattacharyya, S. (2010). Creativity and Innovation for Competitive Excellence in Organizations, Conference an Global Competition \& Competitiviness of Indian Corporate.

KKLW. (2010). Pelan Induk Pembangunan Luar Bandar (PIPLB). Putrajaya: Kementerian Kemajuan Luar Bandar Dan Wilayah.

Konting, Mohd. Majid. (2004). Kaedah Penyelidikan Pendidikan (5th ed.). Kuala Lumpur: Dewan Bahasa \& Pustaka.

Yusof, Mohd. Abdullah. (2003). Keberkesanan Fungsi Jawatankuasa Kemajuan Dan Keselamatan Kampung (JKKK) Dalam Pembangunan Luar Bandar : Satu Kajian Kes. Universiti Putra Malaysia. 
Munirah, Mohd Hassan. (1997). Participation Of The Village Development And Security Committee Members In Community Development Programmes In Kuching, Sarawak. Universiti Putra Malaysia.

Nambiar, M., \& Kennedy, H. (2012). Organizational Excellence Through Innovation Management. In M. S. Rangaraju, S. H. Kennedy, \& PES Institute of Technology (Bangalore. India) (Eds.), Innovation in management: challenges and opportunities in the next decade (Conference.). New Delhi: Allied Publishers.

Pejabat Daerah Setiu. (2014). Pentadbiran JKKK. Pdtsetiu Online. Retrieved from http://pdtsetiu.terengganu.gov.my/inde x.php?option=com content\&view $=$ article \&id=111\&Itemid=100

Romzi Bin Ationg. (2001). Keberkesanan Kepimpinan Tempatan Dalam Aktiviti Pembangunan Desa di Daerah Kudat, Sabah, Universiti Putra Malaysia

Selznick, P. (1957). Leadership in Administration: A Sociological Interpretation, University of California Press, Berkeley.

Yang, B.-C., Wu, B.-E., Shu, P.-G., \& Yang, M.-H. (2006). "On Establishing The Core Competency Identifying Model: A ValueActivity And Process Oriented Approach",Industrial Management \& Data Systems, Vol. 106 No. 1, pp. 60-80. 